\title{
CORONAVIRUS AID, RELIEF, AND ECONOMIC SECURITY FOR WHOM? IRS OVERREACHES IN DENYING CARES ACT ECONOMIC IMPACT PAYMENTS TO MIGRANT WORKERS AND INCARCERATED INDIVIDUALS
}

\author{
Justin Schwegel \\ INTRODUCTION
}

Individuals who received advance refunds under the Coronavirus Aid, Relief, and Economic Security (CARES) Act met the eligibility criteria in their 2019 tax filings (or 2018 filings if they had not yet filed 2019 taxes). ${ }^{1}$ Advance refunds are treated as a refund of an overpayment of 2018 or 2019 taxes. $^{2}$ Subsequent changes in tax filing status in 2020 do not retroactively make one ineligible for an advance refund. ${ }^{3}$ On May 6 , the IRS issued guidance on its Economic Impact Payment Information Center website instructing incarcerated individuals and certain resident aliens ${ }^{4}$ that they should return the economic impact payments (also called advance refunds or stimulus payments) they received from the IRS. ${ }^{5}$ This guidance is not legally binding for two distinct reasons. First, it was issued without conforming to the procedural requirements of the Administrative Procedure Act. Second, the guidance exceeded the IRS's rulemaking authority because it contradicts unambiguous statutory language.

\footnotetext{
$\dagger$ Justin is a Sarasota, Florida-based attorney with law degrees from Georgetown (JD), the Institut d'études politiques de Paris (international economic law), and the University of Arkansas (agricultural and food law). His academic interests include economic justice, agricultural policy, and government integrity. He extends gratitude to Sarah Bradford and CUNY Law Review staff editors of this article.

${ }^{1}$ I.R.C. $§ 6428(f)(1)$ (2020) (stating that eligibility for an "advance refund" is based on meeting the eligibility criteria in 2019); id. § 6428(f)(5)(A) (stating that where a taxpayer has not filed 2019 taxes, 2018 taxes may be used to determine eligibility).

${ }^{2} I d . \S 6428(\mathrm{f})(1)$.

${ }^{3}$ In guidance published on April 17, 2020, the IRS stated, "there is no provision in the law requiring repayment of a payment." The original language is preserved online. See Nina Olson, The Uncertainty of Death and Taxes: Economic Stimulus Payments to Deceased Individuals, Procedurally TaXING (May 11, 2020), https://perma.cc/W8EJ-LRH6. Although this guidance has been reworded slightly to "there is no provision in the law that would require individuals who qualify for a Payment based on their 2018 or 2019 tax returns, to pay back all or part of the payment, if based on the information reported on their 2020 tax returns, they no longer qualify for that amount or would qualify for a lesser amount," the original statement is a more accurate reading of the statute. Question J3, Economic Impact Payment Information Center — Topic J: Reconciling on Your 2020 Tax Return, IRS, https://perma.cc/LLU6-DJS3 (last updated Dec. 8, 2020).

${ }^{4}$ The CARES Act distinguishes between "resident aliens," who must pay U.S. taxes, and "nonresident aliens," who need not. While the designation "alien" is an antiquated and offensive term carrying powerful connotation, it continues to be a common legal term of art in U.S. tax law and regulation. In the interest of avoiding the confusion inherent in using language inconsistent with statutory and regulatory text, this term will be used throughout this work.

${ }^{5}$ Questions A13 and A14, Economic Impact Payment Information Center - Topic A: EIP Eligibility, IRS, https://perma.cc/ZY3D-93L4 (last updated Dec. 8, 2020). The numeration on the guidance has changed from the original publication and the guidance has been updated to reflect a permanent injunction against the IRS from withholding advance refunds from incarcerated individuals. The original language and numeration is available at https://web.archive.org/web/20201002001941/https://www.irs.gov/newsroom/economic-impact-paymentinformation-center-topic-a-eip-eligibility-and-general-information\#collapseCollapsible1601555603679.
} 


\section{CONTEXT}

The coronavirus and attendant economic downturn have led to the worst unemployment crisis since the Great Depression, and many families have begun to feel the pinch. ${ }^{6}$ The March 2020 increase in unemployment was the worst since January 1975 as the number of unemployed people increased by 1.4 million. ${ }^{7}$ Congress responded, in part, with bipartisan stimulus legislation signed into law on March 27, 2020 that included enhanced unemployment benefits, relief for small businesses, financial support for state, local, and tribal governments, and a one-time stimulus payment for eligible individuals. ${ }^{8}$ In its haste to distribute the stimulus, Congress based eligibility for the stimulus payment on information the federal government already had in its possession: past tax filings. ${ }^{9}$ Under the plain meaning of the legislation, incarcerated individuals and migrant workers, who received economic impact payments because they were eligible based on past tax filings, are allowed to keep them notwithstanding IRS guidance to the contrary. ${ }^{10}$

\section{STIMULUS PAYMENT ELIGIBILITY AND FUNCTION}

Section 2201 of the Coronavirus Aid, Relief, and Economic Security (CARES) Act ${ }^{11}$ provided for recovery rebates for individuals, also known as stimulus payments. ${ }^{12}$ This was accomplished by adding a new section to the Internal Revenue Code that created a refundable tax credit if individuals meet certain eligibility criteria. ${ }^{13}$ Congress defined eligibility for both the advance refund in 2020 and the refundable credit in 2021 by creating an exhaustive list of all classes of individuals who are not eligible for the credit, and stipulated at what time the eligibility criteria must be met.

The governing statute, 26 U.S.C. $§ 6428(\mathrm{~d})$, defines "eligible individuals" as: any individual other than a nonresident alien; any individual with respect to whom a deduction under section 151 is allowable to another taxpayer for a taxable year beginning in the calendar year in which the individual's taxable year begins (i.e., a dependent); or an estate or a trust. ${ }^{14}$ Additionally, individuals are not eligible if, in the relevant tax year, they do not include on their tax filings a Social Security number, their spouse's Social Security number (if filing jointly), or their child's Social Security number (if claiming a dependent child). ${ }^{15}$

The CARES Act also defined the time at which eligibility criteria must be met. For advance refunds of credit, an individual is eligible if that person "was an eligible individual for such

\footnotetext{
${ }^{6}$ Derek Thompson, It's the Pandemic, Stupid, ATLANTIC (May 8, 2020), https://perma.cc/836N-R2U7.

${ }^{7}$ Bureau of Labor Statistics, U.S. DeP'T Of Labor, The Employment Situation - March 2020 at 2 (Apr. 3, 2020), https://perma.cc/4LWR-43TH.

${ }^{8}$ The CARES Act Works for All Americans, U.S. DEP'T OF TREASURY, https://perma.cc/AU2N-FZD5 (last visited Dec. 29, 2020). It should be noted that this stimulus payment is called variably an "economic impact payment," a "recovery rebate" and an "advance refund of a recovery rebate credit," but these all refer to the same thing.

${ }^{9}$ See I.R.C. § 6428(f)(1) (2020); see also id. § 6428(f)(5)(A).

${ }^{10}$ See id. $\S 6428(\mathrm{f})(1)$; see also id. $\S 6428(\mathrm{f})(5)(\mathrm{A})$; Olson, supra note 3.

${ }^{11}$ Coronavirus Aid, Relief, and Economic Security (CARES) Act, Pub. L. No. 116-136, § 2201, 134 Stat. 281, 335-

$40(2020)$.

${ }^{12} I d . \S 2201(\mathrm{a})$.

${ }^{13}$ I.R.C. $\S 6428$

${ }^{14} \mathrm{Id} . \S 6428(\mathrm{~d})$.

${ }^{15} \mathrm{Id}$. $\S 6428(\mathrm{~g})$.
} 
individual's first taxable year beginning in 2019."16 Because the IRS moved the 2019 tax filing deadline from April 15 to July 15, 2020 and many people had not filed taxes when the CARES Act was passed, Congress stipulated that for those who had not yet filed a 2019 tax return, eligibility for an advance refund would be determined by 2018 tax filings. ${ }^{17}$ Anyone who was not in one of the classes of ineligible individuals defined by 26 U.S.C. $\S$ 6428(d) in 2019 (or 2018 if applicable) was to be treated as having overpaid 2019 taxes in the amount of the stimulus. ${ }^{18}$

Those who are not eligible for an advance refund may still qualify for a credit in 2021. Eligibility for a credit when filing 2020 taxes in April 2021 is based on the relevant criteria for the 2020 tax year. ${ }^{19}$ Any advance refund received in 2020 will reduce the credit individuals are eligible to receive when filing 2020 taxes in 2021, but not below zero. ${ }^{20}$ As the IRS stated on April 17, 2020 , "there is no provision in the law requiring repayment of a payment.".21

As noted above, an individual who met eligibility criteria in 2019 shall be treated as if they made an overpayment of income tax in that year. Consequently, stimulus payments received as an advance refund function as a reimbursement of income tax overpayment in 2019. Nothing in the statute requires repayment should an individual not be eligible in the 2020 tax year. ${ }^{22}$

If the IRS sent an individual a tax refund for overpaying 2019 taxes because they claimed a credit for which they were eligible, it would be bizarre to demand repayment simply because that individual does not qualify for the credit in 2020. Yet, for incarcerated individuals and some migrant workers, that is exactly what the IRS did. ${ }^{23}$

This is especially perplexing because the IRS does not treat other stimulus recipients this way. For example, a parent may have received an additional $\$ 500$ stimulus payment because she had an eligible dependent on her 2019 tax filings. ${ }^{24}$ The IRS has advised such a parent that she need not return the $\$ 500$ if the child is no longer a qualifying dependent on 2020 tax filings. ${ }^{25}$

${ }^{16} I d . \S 6428(\mathrm{f})(1)$ (emphasis added).

${ }^{17} I d . \S 6428(\mathrm{f})(5)(\mathrm{A})$.

${ }^{18} I d . \S 6428(\mathrm{f})(3)(\mathrm{A})$.

${ }^{19} \mathrm{Id}$. $\S 6428$ (a) (providing a credit to eligible individuals filing 2020 taxes).

${ }^{20}$ Id. $\S 6428(\mathrm{e})(1)$.

${ }^{21}$ IRS, supra note 3.

${ }^{22}$ I.R.C. § 6428(f)(3).

${ }^{23}$ During this article's revision, incarcerated individuals successfully sued the IRS to reverse this position. See Scholl v. Mnuchin, No. 20-cv-05309-PJH, 2020 WL 5702129 (N.D. Cal. Sept. 24, 2020), perm. app. granted, Scholl v. Mnuchin, No. 20-17077 (9th Cir. Dec. 11, 2020). IRS guidance was subsequently updated with respect to incarcerated individuals. Of ongoing concern is that the IRS has prohibited tax authorities from at least one insular territory, the U.S. Virgin Islands, from distributing economic impact payments to incarcerated individuals under an Economic Impact Payment Implementation Plan. Complaint at 1, Morton v. U.S. Virgin Islands, No. 3:20-cv-109 (V.I Nov. 3, 2020). The Economic Impact Payment Implementation Plans for other U.S. insular territories such as Puerto Rico are not publicly available. Telephone Interview with David J. Kautter, Assistant Sec'y for Tax Policy, Dep't of the Treasury (Dec. 21, 2020).

${ }^{24}$ I.R.C. § 6428(a)(2).

${ }^{25}$ IRS, supra note 3. Per IRS guidance, there is "no provision in the law that would require individuals who qualify for a Payment based on their 2018 or 2019 tax returns, to pay back all or part of the payment, if based on the information reported on their 2020 tax returns, they no longer qualify for that amount or would qualify for a lesser amount." Id. The IRS provided the following example: Where "you received $\$ 500$ for your child who, based on your 2018 or 2019 tax return, met the qualifying child requirements. That child turned 17 in 2020 and no longer meets the qualifying child requirements. You will not be required to pay back the $\$ 500$." Id. 
Likewise, a tax filer who received an advance refund based on 2019 filings, but who has earned so much income in 2020 she will not qualify, will not need to return the payment. On the contrary, on April 17, 2020, the IRS assured such individuals that "there is no provision in the law requiring repayment of a payment." 26

\section{IRS GUIDANCE}

The CARES Act's language is clear in that it requires no repayment of stimulus checks, ${ }^{27}$ and the IRS recognized as much. ${ }^{28}$ However, the IRS advised some individuals who received advance refunds because they met eligibility criteria in 2019 tax filings to return their payments. ${ }^{29}$ Specifically, the IRS instructed both incarcerated persons and aliens who were U.S. tax residents in 2019, but may not be resident aliens in 2020 , to return stimulus payments. ${ }^{30}$ For migrant workers who were U.S. tax residents in 2019, this guidance is legally erroneous. Migrant workers met the eligibility criteria when they were required to do so under the clear language of the statute. For incarcerated individuals, this guidance is egregiously erroneous because they will likely continue to meet eligibility criteria in 2020 .

After the IRS changed its guidance to instruct incarcerated individuals to return stimulus payments, it provided guidance to correctional facilities to intercept and return checks and remove incarcerated individuals from payment tranches distributed from May 1, 2020 onward. ${ }^{31}$ A class action was filed on behalf of incarcerated individuals, and the IRS was permanently enjoined from withholding stimulus payments from incarcerated individuals on October 14, 2020. ${ }^{32}$ On October 29 , in response to the permanent injunction, the IRS modified its guidance for incarcerated individuals to reflect the court's ruling that incarcerated individuals are eligible to receive stimulus payments pending the IRS's appeal to the 9th Circuit Court of Appeals. ${ }^{33}$ That appeal was subsequently dismissed with prejudice. ${ }^{34}$ The guidance to individuals classified as resident aliens in 2018 and 2019, but who will see a tax residency status change in 2020, has not changed. ${ }^{35}$

\footnotetext{
${ }^{26}$ IRS, supra note 3.

${ }^{27}$ I.R.C. $\S 6428(\mathrm{e})(1)$ (stating that although advance payment will reduce the credit for the 2020 tax year, it will not reduce the credit below zero).

${ }^{28}$ IRS, supra note 3.

${ }^{29}$ Questions A13 and A14, Economic Impact Payment Information Center - Topic A: EIP Eligibility, IRS (last updated Oct. 1, 2020), https://web.archive.org/web/20201002001941/https://www.irs.gov/newsroom/economicimpact-payment-information-center-topic-a-eip-eligibility-and-generalinformation\#collapseCollapsible1601555603679.

${ }^{30}$ See id. at Question A14. This category could particularly impact H-2A and H-2B nonimmigrant visa holders.

${ }^{31}$ Scholl v. Mnuchin, No. 20-cv-05309-PJH, 2020 WL 5702129, at*3 (N.D. Cal. Sept. 24, 2020) (granting preliminary injunction and class certification).

${ }^{32}$ Scholl v. Mnuchin, No. 20-cv-05309-PJH, 2020 WL 6065059, at*1 (N.D. Cal. Oct. 14, 2020) (granting in part and denying in part a motion for summary judgment and denying a motion for stay).

${ }^{3}$ Question A7, Economic Impact Payment Information Center - Topic A: EIP Eligibility, IRS, https://perma.cc/3X9J-HYR8 (last updated Dec. 8, 2020).

${ }^{34}$ Scholl v. Mnuchin, No. 20-cv-05309-PJH, 2020 WL 5702129 (N.D. Cal. Sept. 24, 2020), perm. app. granted, Scholl v. Mnuchin, No. 20-17077 (9th Cir. Dec. 11, 2020).

${ }^{35}$ Question A6, Economic Impact Payment Information Center — Topic A: EIP Eligibility, IRS, https://www.irs.gov/newsroom/economic-impact-payment-information-center-topic-a-eip-eligibility (last updated Dec. 8, 2020).
} 
The guidance ${ }^{36}$ to migrant workers and incarcerated individuals is not legally binding and should not be persuasive to a court interpreting the statute. It is not legally binding because only legislative rules are legally binding, and the guidance was issued without conforming to the procedural requirements the Administrative Procedure Act established for legislative rules. Second, the guidance exceeded the IRS's rulemaking authority because it contradicts unambiguous statutory language.

\section{A. The IRS guidance is not legally binding because it was not lawfully issued.}

The IRS guidance is not legally binding for two independent reasons. First, a rule must be either a legislative rule or a nonlegislative rule. If it was a legislative rule, it was improperly adopted because the IRS did not follow the notice and comment rulemaking process. ${ }^{37}$ The Supreme Court has held that nonlegislative rules are not legally binding, though they may be persuasive if they meet certain factors. ${ }^{38}$ Second, the rule is improper because it directly contradicts the statutory language that it purports to interpret.

Legislative rules have legally binding effect and are accorded broad deference by courts. ${ }^{39}$ Section 553 of the Administrative Procedure Act describes the requirements for adoption of legislative rules. ${ }^{40}$ It requires that "[g]eneral notice of proposed rulemaking ... be published in the Federal Register" to provide interested persons with an opportunity "to participate in the rule making through submission of written data, views, or arguments," a process more commonly known as notice and comment rulemaking. ${ }^{41}$ The obligation to undertake notice and comment rulemaking does not apply to "interpretive rules" and "general statements of policy," collectively referred to as "nonlegislative rules." 42 Additionally, "when the agency for good cause finds ... that notice and public procedure thereon are impracticable, unnecessary, or contrary to the public interest," such as in an emergency situation, it can dispense with the requirement but must incorporate that finding "and a brief statement of reasons therefor in the rules issued." 43 The IRS did not do so here. Where a legislative rule is adopted without notice and comment rulemaking, the rule is invalid. ${ }^{44}$

\footnotetext{
${ }^{36}$ Here, "the guidance" refers to the original guidance provided to both resident aliens and incarcerated individuals. While the guidance has been modified for incarcerated individuals, "the guidance" will refer to the original guidance and, for the sake of grammatical simplicity, the discussion will use the present tense to refer to guidance that remains applicable to resident aliens, was applicable to incarcerated individuals, and still impacts incarcerated individuals in some U.S. territories. A recent class action highlights one example of IRS guidance that prohibited U.S. Virgin Islands' tax authorities from distributing economic impact payments to incarcerated individuals under an Economic Impact Payment Implementation Plan. See Complaint, Morton v. U.S. Virgin Islands, No. 3:20-cv-109 (V.I. Nov. 3, 2020).

${ }^{37}$ See e.g., Nat. Res. Def. Council v. EPA, 643 F.3d 311, 323 (D.C. Cir. 2011) (vacating EPA guidance on implementation of the Clean Air Act because it constituted a final rule that did not proceed through notice and comment rulemaking).

${ }^{38}$ Skidmore v. Swift \& Co., 323 U.S. 134, 140 (1944).

${ }^{39}$ See Chevron U.S.A., Inc. v. Nat. Res. Def. Council, Inc., 467 U.S. 837 (1984).

${ }^{40}$ The "formal" rulemaking processes outlined in 5 U.S.C. $\$ \S 556$ and 557 are not relevant here and will not be addressed.

${ }^{41} 5$ U.S.C. $\S 553(b)-(c)(2020)$.

${ }^{42} I d . \S 553(\mathrm{~b})$.

${ }^{43} I d . \S 553(\mathrm{~b})(3)(\mathrm{B})$.

${ }^{44}$ E.g. Nat. Res. Def. Council v. EPA, 643 F.3d 311, 321 (D.C. Cir. 2011).
} 
Because legislative rules generally must undergo notice and comment rulemaking while nonlegislative rules need not, there is the potential for some ambiguity as to whether a rule is an improperly adopted (and therefore invalid) legislative rule, or simply a nonlegislative rule. ${ }^{45}$ The legal tests that courts use to determine whether a rule issued without notice and comment is nonetheless a legislative rule are "fuzzy," "tenuous," "blurred," "baffling," and "enshrouded in considerable smog." "46 Even so, courts often look to "whether in the absence of the rule there would ... be an adequate legislative basis ...[to] ensure the performance of duties," 47 or whether the agency is creating a new entitlement or obligation-i.e., whether the rule requires someone to do or refrain from doing something, or confers a benefit upon them, that the legislation alone does not. $^{48}$

In its Internal Revenue Manual, the IRS notes that "when a statutory provision does not provide adequate authority for the regulatory action taken" the IRS must engage in legislative rulemaking. ${ }^{49}$ The IRS itself pointed out that "there is no provision in the law requiring repayment of a payment," ${ }^{\circ}$ and there is nothing in the plain language of the CARES Act denying the advance refunds to incarcerated individuals or 2019 resident aliens, or requiring them to repay the advance refund if their residency status changes in 2020. Consequently, forcing incarcerated persons and 2019 resident aliens to return stimulus payments would impose a new obligation. As such, it is an invalid legislative rule adopted without notice and comment.

Alternatively, if the rule is not a legislative rule, it is by default a nonlegislative rule. A nonlegislative rule is an interpretive rule or general statement of policy. ${ }^{51}$ Interpretive rules, as the name suggests, interpret ambiguous statutes or regulations without creating new legal obligations, ${ }^{52}$ while general statements of policy advise the regulated public of how the agency may prospectively exercise its discretionary power. ${ }^{53}$ Nonlegislative rules are not legally binding, ${ }^{54}$ although courts accord some measure of deference to agency interpretations in litigation based on agency enforcement action. ${ }^{55}$ The Supreme Court stated in Skidmore v. Swift that the amount of deference accorded to an agency's action "will depend upon the thoroughness evident in its

\footnotetext{
45 See generally David L. Franklin, Legislative Rules, Nonlegislative Rules, and the Perils of the Short Cut, 120

YALE L.J. 276 (2010) (discussing the frustrating indeterminacy of distinguishing between legislative and nonlegislative rules, as well as the shortcomings of one proposal to simplify the determination).

${ }^{46} I d$. at 286-87 (first quoting Am. Hosp. Ass'n v. Bowen, 834 F.2d 1037, 1046 (D.C. Cir. 1987); then quoting

Chisholm v. FCC, 538 F.2d 349, 393 (D.C. Cir. 1976) (Wright, J., dissenting); then quoting Cmty. Nutrition Inst. v. Young, 818 F.2d 943, 946 (D.C. Cir. 1987); and then quoting Noel v. Chapman, 508 F.2d 1023, 1030 (2d Cir. 1975)).

${ }^{47}$ Am. Mining Cong. v. Mine Safety \& Health Admin., 995 F.2d 1106, 1112 (D.C. Cir. 1993); see also William Funk, A Primer on Nonlegislative Rules, 53 AdMIN. L. REV. 1321, 1328 (2001).

48 See Funk, supra note 47, at 1332.

${ }^{49}$ In Internal Revenue Manual 32.1.1.2.7, the IRS notes that "when a statutory provision does not provide adequate authority for the regulatory action taken" the IRS must engage in legislative rulemaking. IRM 32.1.1.2.7 (Aug. 2, 2018). The IRS also notes that with respect to the amendment to the Internal Revenue Code affected by the CARES Act, "there is no provision in the law requiring repayment of a payment." IRS, supra note 3. Consequently, any guidance issued by the IRS requiring repayment of a payment would be required to follow the legislative rulemaking process.

${ }^{50}$ IRS, supra note 3.

51 These are the only two types of rules provided for at 5 U.S.C. $\$ 553$. Legislative rules must be published in the Federal Register to provide notice while nonlegislative rules are exempt from this requirement.

52 Funk, supra note 47, at 1324.

${ }^{53}$ Franklin, supra note 45, at 286.

${ }^{54}$ See Chrysler Corp. v. Brown, 441 U.S. 281, 301-02 (1979).

${ }^{55}$ See Skidmore v. Swift \& Co., 323 U.S. 134, 140 (1944).
} 
consideration, the validity of its reasoning, its consistency with earlier and later pronouncements, and all those factors which give it power to persuade." 56

More recently, in United States v. Mead Corp., the Court provided that the deference accorded nonlegislative rules is a function of "the agency's care, its consistency, formality, and relative expertness, and to the persuasiveness of the agency's position." 57

The guidance provided on the IRS's Economic Impact Payment Information Center website does not meet the factors of a persuasive interpretive rule as outlined in Skidmore and Mead. The guidance interprets an unambiguous statute in a manner contrary to its plain text, is not accompanied by any explanation of its reasoning, and is inconsistent with other guidance provided in the same publication. ${ }^{58}$

\section{B. The IRS does not have authority to modify eligibility criteria for advance refunds under the CARES Act.}

Even if it had properly undertaken notice and comment rulemaking, the Department of Treasury would not have the authority to adopt the guidance because the statute specifically addresses the issue of eligibility and is not ambiguous. Under Chevron, U.S.A., Inc. v. Natural Resources Defense Council, only where a statute is "silent or ambiguous with respect to the specific issue," must a court defer to the agency's interpretation, if that interpretation is reasonable..$^{59}$

Congress authorized the Secretary of Treasury to issue "such regulations or other guidance as may be necessary to carry out the purposes of this section, including any such measures as are deemed appropriate to avoid allowing multiple credits or rebates to a taxpayer." ${ }^{.60}$ However, Congress clearly and unambiguously stated the eligibility criteria that individuals must meet to receive the refundable tax credit. ${ }^{61}$ Congress also clearly and unambiguously stipulated when individuals must meet the eligibility criteria. ${ }^{62}$ Congress defined eligibility criteria negatively, i.e.,

\footnotetext{
${ }^{56} \mathrm{Id}$.

${ }^{57}$ United States v. Mead Corp., 533 U.S. 218, 228 (2001).

${ }^{58}$ Compare, IRS, supra note 3 (in which the IRS first states that "there is no provision in the law requiring repayment of a payment" and later, that "there is no provision in the law that would require individuals who qualify for a Payment based on their 2018 or 2019 tax returns, to pay back all or part of the payment"), with IRS, supra note 29 (in which the IRS advises both incarcerated individuals and individuals who are nonresident aliens in 2020 who received payments to "return the Payment to the IRS by following the instructions about repayments").

${ }^{59}$ Chevron U.S.A., Inc. v. Nat. Res. Def. Council, Inc., 467 U.S. 837, 843 (1984); id. at 843 n.9 ("The judiciary is the final authority on issues of statutory construction and must reject administrative constructions which are contrary to clear congressional intent.").

${ }^{60}$ I.R.C. $\$ 6428(\mathrm{~h})$.

${ }^{61}$ See id. $\S 6428$.

${ }^{62} I d$. $\S 6428(\mathrm{f})(1)$ ("[E] ach individual who was an eligible individual for such individual's first taxable year beginning in 2019 shall be treated as having made a payment against the tax imposed by chapter 1 for such taxable year in an amount equal to the advance refund amount for such taxable year."). The use of the past tense "was" for meeting eligibility criteria indicates that if an individual met the eligibility criteria in 2018 or 2019 , they are to be treated as having made an overpayment of their income taxes in the amount of the stimulus.
} 
Congress exhaustively listed all classes of individuals who do not qualify for an advance refund and/or the refundable tax credit. ${ }^{63}$

The Department of Treasury can neither change the eligibility criteria established by Congress, nor add classes of individuals to Congress' exhaustive list of ineligible individuals. Individuals who meet the criteria stipulated in 26 U.S.C. $\S 6428$ (by not being in one of the ineligible classes of individuals) but who are incarcerated are nonetheless eligible for the stimulus payment. Individuals who filed taxes as resident aliens ${ }^{64}$ in $2019^{65}$ with a Social Security number, ${ }^{66}$ who could not have been claimed as a dependent, ${ }^{67}$ and who did not file jointly with a spouse without a Social Security number or a dependent child without a Social Security number ${ }^{68}$ are eligible to receive advance refunds. ${ }^{69}$ If they do not qualify for the refundable credit when filing 2020 taxes, e.g., because of a change in tax residency, the amount they receive in 2021 will be reduced by the amount they received as an advance refund, but not to below zero. ${ }^{70}$

\section{CONCLUSION}

Under the statutory language on stimulus payment eligibility, it is clear that both incarcerated persons and migrant workers who were resident aliens in 2019 should be allowed to keep their stimulus payments. The IRS sought to force incarcerated individuals and 2019 resident aliens to return those payments, despite advising others similarly situated that there is no legal provision requiring repayment. ${ }^{71}$ This guidance was issued in a manner that was procedurally and substantively deficient under the Administrative Procedure Act, which could have a materially adverse effect on vulnerable communities.

The time period during which the IRS may issue advance refunds and credits is statutorily limited. Advance refunds and credits may not be made after December 31, 2020. ${ }^{72}$ After that, individuals will only qualify for the refundable credit if they meet eligibility criteria based on 2020 tax filings. An individual whose eligibility for the stimulus payment changes between 2019 and 2020 tax filings will likely lose out on the payment altogether if they return the advance refund. ${ }^{73}$

\footnotetext{
${ }^{63}$ I.R.C. § 6428(d) defines "eligible individual" as any individual who is not an "ineligible individual." I.R.C. § 6428(d)(1-3) lists the three classes of ineligible individuals. Under the broadly accepted rule of statutory interpretation Expressio unius est exclusio alterius, MERRIAM-WEBSTER.COM LEGAL DiCTIONARY (last visited Dec. 27, 2020), https://perma.cc/QL9U-NWSB (“[A] principle in statutory construction: when one or more things of a class are expressly mentioned others of the same class are excluded."), because Congress explicitly defined which classes of individuals are ineligible, it is implicit that other classes of individuals are eligible.

${ }^{64}$ Under I.R.C. § 6428(d), "resident alien[s]" are "eligible individual[s]" because they are not explicitly ineligible.

${ }^{65}$ I.R.C. $\S 6428(\mathrm{f})(1)$ states that if an individual was an eligible individual in 2019, they are to be treated as having made a tax payment in 2019 equal to the advance refund amount in 2019.

${ }^{66}$ I.R.C. $§ 6428(\mathrm{~g})$.

${ }^{67}$ If they could be claimed as a dependent, they would be defined as an ineligible individual under I.R.C. § 6428(d).

${ }^{68}$ I.R.C. $\S 6428(\mathrm{~g})$.

${ }^{69} \mathrm{Id}$. $\S 6428(\mathrm{f})$.

${ }^{70} \mathrm{Id} . \S 6428(\mathrm{e})$.

${ }^{71}$ IRS, supra note 25.

${ }^{72}$ I.R.C. $\S 6428(\mathrm{f})(3)(\mathrm{A})$.

${ }^{73}$ IRM 21.4.5.5.2(3-8) (Oct. 1, 2020) instructs IRS employees to refer an "erroneous refund" to the Examination Division where it will be recovered with a deficiency assessment. It seems unlikely that a refund or credit recovered in this way could be reissued after December 31,2020 if the next administration determines that the recovery of such refunds was itself erroneous. By contrast, for those eligible individuals whose payments were undeliverable
} 
This could impact many guest workers who were eligible based on 2018 or 2019 tax filings, but who were unable to renew their visas or physically travel to the United States as a result of Covid19. This is also the case for the legal heirs of incarcerated individuals who died in prison in $2020 .^{74}$ As of December 29, 2020, this includes 1,738 prisoners who have died of Covid-19. ${ }^{75}$ It appears the IRS's intent is to recover as many stimulus advance refunds as possible and then run out the clock until January 1, 2021, when it will be statutorily prohibited from reissuing them. This would harm some of the most vulnerable individuals who are eligible to receive payment.

because of, e.g., a change in address, the IRS will "credit the appropriate taxpayer's account" under IRM 21.4.3.5.3(2) (Oct. 1, 2020), and it is possible that they could still obtain the refundable credit in future tax years. Crediting the account would mean that the advance payment was made prior to December 31, 2020 as required by I.R.C. $\S 6428(\mathrm{f})(3)(\mathrm{A})$. This could also impact the estates of individuals who were eligible individuals in 2018 or 2019 as they have likewise been erroneously instructed by the IRS to return the Economic Impact Payments.

${ }^{74}$ Although the IRS is no longer defending this suit, the IRS's Economic Impact Payment Implementation Policy for at least one insular territory continues to prohibit tax authorities from distributing economic impact payments to incarcerated individuals. See Complaint, Morton v. U.S. Virgin Islands, No. 3:20-cv-109 (V.I. Nov. 3, 2020). It is unclear whether this is true for the implementation plans for other U.S. insular territories. See IRS, supra note 25.

${ }^{75}$ A State-by-State Look at Coronavirus in Prisons, MARSHALL ProJeCT, https://perma.cc/Q85E-9RL2 (last updated Dec. 18, 2020, 12:35 PM). At the time of this article's publication, the number of coronavirus deaths in United States prisons has continued to rise. 